\title{
Financial Literacy Effect and Fintech in Investment Decision Making
}

\author{
Yopy Junianto ${ }^{1)}$ \\ yopy.junianto@ciputra.ac.id \\ Cliff Kohardinata2) \\ ckohardinata@ciputra.ac.id \\ Diana Silaswara ${ }^{3)}$ \\ diana.silaswara@ubd.ac.id \\ 1)2)Universitas Ciputra - Surabaya \\ 3)Universitas Buddhi Dharma - Tangerang
}

\begin{abstract}
Indonesia is a country that has a fairly good level of investment from year to year, based on KSEI 2020 data. This indicates that Indonesia's business opportunities are quite promising. This increase in investment was also followed by technological developments in the financial sector as we know fintech. The results of this fintech product have been widely used by many groups, especially for investment activities. This is one of the driving points for increasing investment in Indonesia. In general, investments are usually made by people who have sufficient literacy skills. Because various experiences state that someone who has good financial literacy will be able to make good decisions in terms of finances that have both short and long term impacts. However, the current condition has a different pattern where even without financial literacy the cloud community is currently able to invest even if they only get a little information. This research was conducted to see and explain the phenomena that occurred and provide confirmation that the shift in perspective patterns occurred. The result of the research states that financial literacy does not influence a person in making decisions, while fintech is a factor that influences someone in making investment decisions.
\end{abstract}

Keywords: Financial Literacy, Fintech, Investment , Decision Making 


\section{INTRODUCTION}

Investment decision making in Indonesia is classified as a fairly active investment and has increased from year to year. This happened because of the big opportunity to get the promising returns (yield) on investment in the capital market. Investment is a commitment to a number of funds or other resources for the time being to get the profit in the future (Tandelilin, 2010: 2). The increasing can be seen in Single Investor Identification (SID) or the number of individual investors based on KSEI data which shows an increase in the last 4 years from 2017 - 2020 in Figure 1. Figure 1 shows that from 2017 to 2020 the total number of investors has increased. Mutual funds have been the favorite choice of investors since 2018. Throughout this year until August 31, 2020, mutual funds have attracted 2,447,272 investors registered in SID. The figure jumped to $37.9 \%$ compared to 2019. Meanwhile, at the same time, investors' share has increased $19.4 \%$ to $1,319,141$ SID. Government securities (SBN) also rose $25.8 \%$ to 397,781 SID.

Figure 1.1 Increasement of the number of individual investor 2017-2020

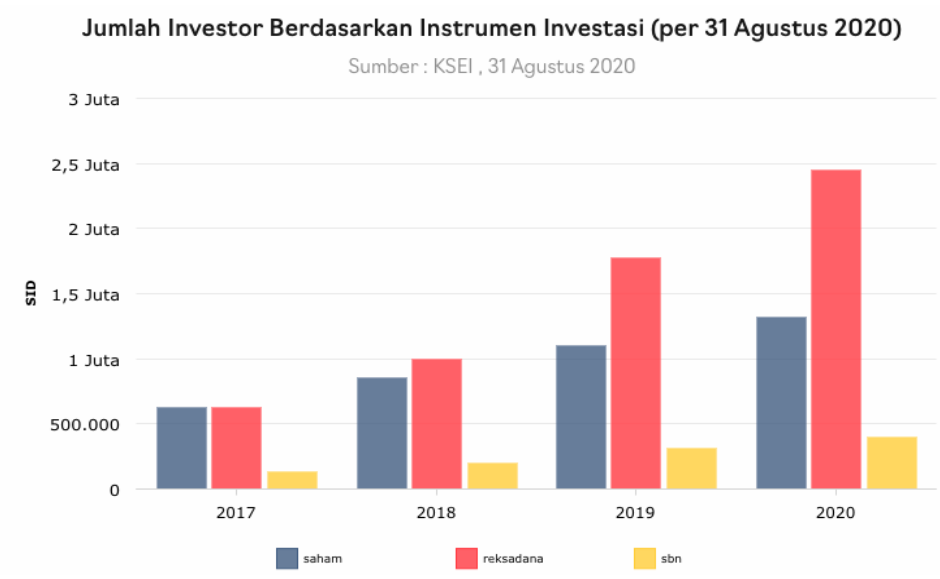

Source : KSEI 2020 
Figure 2.1 Type of investment

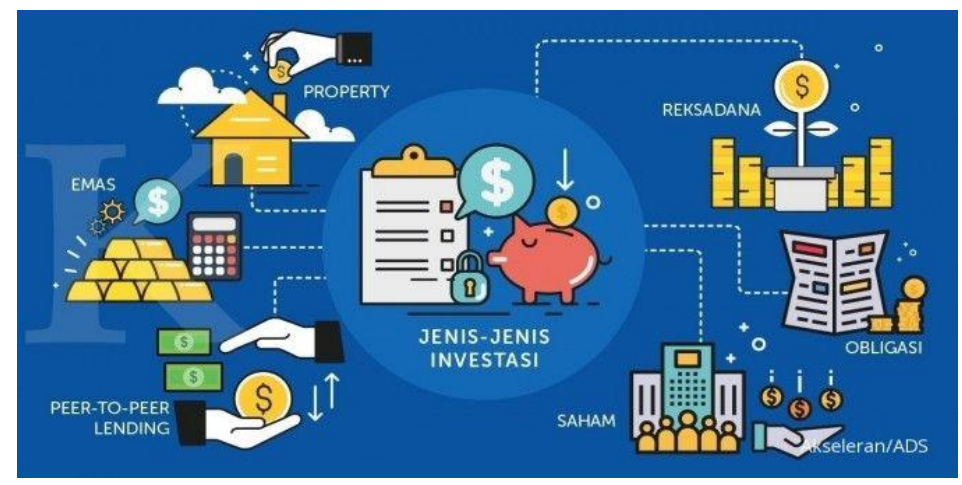

Source : www.kontan.co.id (2018)

This increasement of investor is certainly inseparable from an increase in people's ability to manage finances, which causes the level of public awareness of investment to increase. The desire to earn more income in the future, as well as being driven by a high level of economic need, can cause the pattern of public financial arrangements to begin to change. Investments are an attractive option to get additional income beyond wages or monthly income that is received every month. An investment decision is a decision taken on two or more alternative investments in the hope that they will get benefits in the future (Budiarto \& Susanti, 2017). Increasing investors, this can show the more investment decisions that have been made by new investors.

According to (Awais. et al., 2016) financial literacy is knowledge of individual finances which is used to make financial decisions through prospect analysis or the best short and long term outlook. That with the increase in financial literacy, someone gives positive confidence to take and develop any investment decisions they have.

Studies on (Aren \& Zengin. et al., 2016) explain that financial literacy has a positive effect on investment decisions. However, it is different from research (Arianti, 2018; Budiarto \& Susanti, 2017; Pradhana, 2018) which gives different results that financial literacy has no influence on investment decisions. Researchers saw a phenomenon about the inconsistency of financial literacy, whether financial literacy is still used in this digital era or has its function shifted due to the emergence of technology today. 
The era of technology 4.0 as it is today, making investment decisions is also influenced by fintech factors, fintech is the use of financial system technology that is able to produce new products, services, technology and business models and has an impact on monetary stability, financial system, efficiency, security and system reliability. payment. The presence of fintech is able to have a positive impact on the economy, because people are given the convenience of making transactions and investing. Only through smartphones can people carry out trade and investment activities by only taking one step, installing the application then doing one click step, then the community has met the customer and is ready to make transactions. In this era of all digital fintech has been able to transform financial information into a Information that can be accessed easily and not only that, the role of fintech has also been able to provide various easy options for the general public even though they can understand investment through simple information, without having to look at very detailed information.

From the above phenomenon, the writer sees a shift in the value of the mindset of the public regarding financial literacy which is caused by the development of technology. Behavioral in society has experienced development, according to Lintner (1998: 7), financial behavior is the study of how humans interpret and act on information to make investment decisions. For this reason, the authors conducted research on "whether financial literacy and fintech affect investment decision making". This research will answer the phenomenon of increasing interest in investing in the last 1-2 years which has increased. Whether through improved financial literacy and the role of fintech has led to the increasement in investment interest. 


\section{LITERATURE REVIEW}

\section{Elaboration Likelihood Model (ELM)}

Elaboration Likelihood Model ((ELM) is a comprehensive theory of attitude formation and change that determines the process by which various sources, messages, recipients and context factors are known to influence attitudes (Petty and Brinol, 2014). ELM aims to explain various ways of processing. suggestions, why they are used and the results on attitude change ELM proposes two routes to persuasion

1. The central path, namely the mindset of making a decision based on the ability for rational evaluation to think about points of cost, reliability, efficiency, etc.

2. Peripheral path, namely the thought pattern of making a decision on an emotional basis.Of the two routes to persuasion it can be explained that when a person encounters a form of information, they can process this communication with various levels of thought, from low to high levels of thought.

\section{Financial Literacy}

Financial literacy is the knowledge and skills to apply understanding concepts and risks, the ability to make effective decisions in a financial context to improve financial well-being, both individually and socially, and participate in society (Kemendikbud, 2017)

Otoritas Jasa Keuangan (OJK) stated that the financial literacy program has an important mission, namely how to increase education to the public about good financial management so that people can have knowledge of the financial industry, so that people are not easily fooled by investment products that offer high returns in the short term without considering risks.

Financial literacy is the rotor or driving force in economic functions, with the transactions that are created; the wheels of the economy rotate perfectly. Financial literacy has long-term goals for all groups of society, by increasing a person's literacy 
capacity from being less literate to being well literate can increase the number of users of financial products and services.

According to Remond (2010: 279) the concept of financial literacy focuses on 5 things:

1. Knowledge of financial concepts

2. Ability to communicate financial concepts

3. Ability to manage personal finances

4. Ability to make financial decisions

5. Confidence in financial planning

\section{Financial Technology (Fintech)}

Financial Technology is defined as the transformation of financial services through a technology that can produce business model models, applications, processes and products with material effects related to financial services (Financial Stability Board, 2017).With the existence of fintech, the wider community has become easier to get access to financial products and financial literacy (Finansialku.com, 2018).

There are several types of fintech classifications, namely:

1. Crowdfunding and Peer to Peer Lending

is a funding model for a business unit or project that involves humans at large (kemenkeu.o.id, 2017) Peer to peer lending (P2P) is a form of the practice of providing money lending to individuals linking borrowers and lenders or online investors (Koinwork). com, 2018)

2. Market Aggregators is a data management that can be used by consumers to help make decisions (CNBC Indonesia, 2018)

3. Risk and Investment Management is a planning in digital form by managing risk and management investment 


\section{Payment, Settlement and Clearing}

is the fintech sector which is used for payment system services whether it is carried out by the banking industry or Bank Indonesia Institutions (CNBC Indonesia, 2018).

\section{Investment Decision}

An investment decision is a policy or a decision taken to invest in one or more assets or how someone should allocate funds into the form of investment which can bring benefits at a later date (Wulandari \& Iramani, 2014: 57). According to Dewi \& Purbawangsa (2018: 1876) investment decision making is the process of making conclusions and making decisions on several problems, making choices between two or more investment alternatives or part of transforming inputs into outputs.

In investing, there are five factors that influence investment choices according to Yulianti \& Silvy (2013: 60-61), namely:

1. Level of security and risk

2. Risk components

3. Investment income

4. Investment growth

5. Liquidity

\section{The Effect of Financial Literacy on Investment Decisions}

If someone has good financial literacy, then several things show the level of tendency to be smarter when facing an investment decision. According to research (Aren \& Zengin, 2016; Fachrudin \& Fachrudin, 2016; Ullah, 2015) it explains the positive effect of financial literacy on investment decisions. In contrast to research (Arianti, 2018; Budiarto \& Susanti, 2017; Pradhana, 2018) which provides research results that financial literacy has no influence on investment decisions.

The Influence of Fintech on Investment Decision 
Fintech really helps people to more easily access financial products (finansialku.com, 2018). The community is directly motivated by the changing times where in today's era all necessities of life have been made easy by an application or program and even transactions no longer use paper money, but transactions have used virtual money. Besides that, the big difference with the existence of this fintech is the ease of investing. Where people just need to install an application then with only a little capital understanding of financial literacy, people in today's modern era can invest safely and clearly. Investment decisions no longer use detailed financial information like in the previous era. Only with the information of public investment risk and interest rates, people are now able to determine the investment options. Fintech directly brings together the parties to conduct financial transactions guaranteed by technology security.

\section{RESEARCH METHOD}

This study uses the main data source from a questionnaire, where data collection uses a Likert scale model, according to Siregar (2014: 25). The Likert scale is a scale that can be used to measure a person's attitudes, opinions, and perceptions about an object or phenomenon. The subjects of this research are students who are members of the investment gallery at Ciputra University and young professionals who already have fintech-based investments both in Surabaya and Jakarta with a total of 40 people as research respondents. The secondary data used in research such as literature studies, scientific articles / journals and publication data are relevant in this research. Data analysis techniques include: validity and reliability of research instruments, classical assumption test 


\section{Research Model}

This study analyzes the relationship between financial literacy and fintech on investment decisions. The analysis method used is multiple linear regression. The conceptual model can be seen in Figure 2.3

Figure 2.3 the concept of the research model

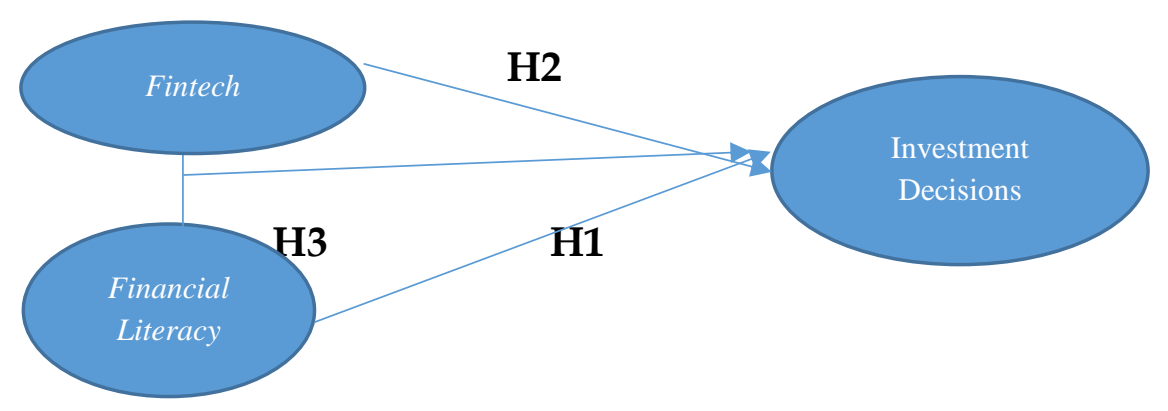

The research method uses a descriptive verification approach. Descriptive research was conducted to identify and explain the variables under study, while verification aims to test the causality of the relationship between research variables (Sekaran, 2006). For questions related to financial literacy, adopting from (Lusardi et al., 2010), (Clark et al., 2017) (Atkinson \& Messy, 2012) is related to basic financial concepts such as time value of money, interest rate on savings and compound interest; inflation; personal income tax. As for the dependent variable, namely fintech, according to (Billion, 2016) relating to ease of transactions, increasing the number of customers or customers, is an easy-to-use application. Meanwhile, investment decisions are measured using; risk (risk); return, and diversification of risk (Tendelilin, 2010), (Atkinson \& Messy, 2012), (Lusardi \& Mitchell, 2014).

Hypothesis

H1: There is an effect of financial literacy on investment decisions.

$\mathrm{H} 2$ : There is an effect of fintech on making investment decisions.

H3: There is a simultaneous influence of financial literacy and fintech on investment decision. 


\section{RESULT AND DISCUSSION}

\section{Validity test}

Validity is a measurement that shows the level of accuracy (validity) of the measure of an instrument against the concept under study (Suharso, 2009: 108). The validity test was carried out with a significance level of $r$ table $5 \%(0.05)$. The calculated value is obtained from the correlation of the answers of each respondent. While the value of $r$ table is obtained from the product moment $\mathrm{r}$ table with alpha significance of $5 \%(0.05)$, then the two-sided $\mathrm{r}$ table with degrees of freedom $(\mathrm{df})=\mathrm{N}-2=38$ is obtained at 0.320 . With the condition that if $\mathrm{r}$ count $>\mathrm{r}$ table, then the instrument is declared valid. Meanwhile, if $\mathrm{r}$ count $<\mathrm{r}$ table, then the instrument is declared invalid. The following is a table of the results of the pre-test validity.

Table 1.1 The result of validity test

\begin{tabular}{|l|r|r|l|}
\hline Item & R Count & \multicolumn{1}{l|}{ R tabel } & Remark \\
\hline LK1 & 0,565 & 0,32 & Valid \\
\hline LK2 & 0,664 & 0,32 & Valid \\
\hline LK3 & 0,625 & 0,32 & Valid \\
\hline LK4 & 0,654 & 0,32 & Valid \\
\hline LK5 & 0,549 & 0,32 & Valid \\
\hline LK6 & 0,451 & 0,32 & Valid \\
\hline LK7 & 0,593 & 0,32 & Valid \\
\hline LK8 & 0,451 & 0,32 & Valid \\
\hline LK 9 & 0,556 & 0,32 & Valid \\
\hline LK10 & 0,633 & 0,32 & Valid \\
\hline LK11 & 0,524 & 0,32 & Valid \\
\hline LK12 & 0,759 & 0,32 & Valid \\
\hline LK13 & 1,316 & 0,32 & Valid \\
\hline FIN1 & 0,78 & 0,32 & Valid \\
\hline FIN2 & 0,818 & 0,32 & Valid \\
\hline FIN3 & 0,905 & 0,32 & Valid \\
\hline FIN4 & 0,912 & 0,32 & Valid \\
\hline FIN5 & 0,93 & 0,32 & Valid \\
\hline FIN6 & 0,885 & 0,32 & Valid \\
\hline FIN7 & 0,932 & 0,32 & Valid \\
\hline FINB & 0,844 & 0,32 & Valid \\
\hline FIN9 & 0,862 & 0,32 & Valid \\
\hline FIN10 & 0,67 & 0,32 & Valid \\
\hline FIN11 & 0,728 & 0,32 & Valid \\
\hline FIN12 & 0,827 & 0,32 & Valid \\
\hline FIN13 & 0,762 & 0,32 & Valid \\
\hline FIN14 & 0,739 & 0,32 & Valid \\
\hline FIN15 & 0,805 & 0,32 & Valid \\
\hline KI1 & 0,443 & 0,32 & Valid \\
\hline KI2 & 0,396 & 0,32 & Valid \\
\hline KI3 & 0,818 & 0,32 & Valid \\
\hline KI4 & 0,717 & 0,32 & Valid \\
\hline KI5 & 0,32 & Valid \\
\hline KI6 & 0,32 & Valid \\
\hline KI7 & 0,32 & Valid \\
\hline
\end{tabular}

Based on table 1.1, all items of the variable financial literacy, fintech, investment decisions have a valid value of $r$ count $>r$ table $(0.321)$. 


\section{Reliability Test}

The reliability test aims to determine the extent to which the measurement results remain consistent if the measurement is carried out twice or more with the same symptoms using the same measuring instrument (Siregar, 2014: 55). Reliability testing will be carried out using Cronbach's Alpha. The criterion for the reliability of the research instrument is if the reliability coefficient $(\mathrm{r} 11)>0.6$. The following table shows the test results

Table 1.2 The result of reliability test

\begin{tabular}{|l|r|r|}
\hline & Cronbach's Alpha & N of item \\
\hline LK & 0,817 & 13 \\
\hline FIN & 0,967 & 15 \\
\hline KI & 0,777 & 7 \\
\hline
\end{tabular}

From the results of the reliability test, it shows that both the variable financial literacy (LK), fintech (fin) and investment decisions have a value greater than 0.6 . So that it can be said that the instrument or questionnaire is reliable.

\section{Multicollinearity Test}

Multicollinearity test is used to test whether there is a high correlation between the independent variables. Multicollinearity can be seen from the tolerance value and the opposite is the variance inflation factor (VIF). If the VIF value is less than 10 and the tolerance is more than 0.10 , then the regression model is free from multicollinearity (Priyatno, 2016: 116). The following table shows the results of the multicollinearity test:

Table 1.4 The result of multicollinearity test

\begin{tabular}{|c|c|c|c|c|c|c|c|c|}
\hline \multicolumn{9}{|c|}{ Coefficients $^{a}$} \\
\hline & & \multicolumn{2}{|c|}{ Unstandardized Coefficients } & \multirow{2}{*}{$\begin{array}{c}\text { Standardized } \\
\text { Coefficients } \\
\text { Beta }\end{array}$} & \multirow[b]{2}{*}{$\mathrm{t}$} & \multirow[b]{2}{*}{ Sig. } & \multicolumn{2}{|c|}{ Collinearity Statistics } \\
\hline Model & & B & Std. Error & & & & Tolerance & VIF \\
\hline \multirow[t]{3}{*}{1} & (Constant) & 4.514 & 4.468 & & 1.010 & .319 & & \\
\hline & TOTAL_LK & .117 & .077 & .165 & 1.514 & .139 & .990 & 1.010 \\
\hline & TOTAL_FIN & .258 & .039 & .718 & 6.607 & .000 & .990 & 1.010 \\
\hline
\end{tabular}


Based on Table 1.4 the tolerance value of the two variables is more than 0.10 , namely 0.990 and the VIF value is less than 10, namely 1.010. So, it can be concluded that there is no multicollinearity between the independent variables.

\section{Heteroscedasticity Test}

Heteroscedasticity test was performed to test the residual variance from one observation to another. A regression model that meets the requirements is that there is a similarity in variance from one residual observation to another fixed observation or it is also called homoscedasticity. The method used in heteroscedasticity testing is the Glejser Test, which is carried out by regressing the residual values with each dependent variable, and the regression model residuals are said to have no heteroscedasticity problems if the significance level is $>a$. In this study, $a=5 \%$ (0.05) (Ghozali, 2011: 143). The following table shows the results of the heteroscedasticity test:

Table 1.5 The result of heteroscedasticity test

\section{Coefficients $^{\mathrm{a}}$}

\begin{tabular}{|c|c|c|c|c|c|c|}
\hline \multirow{2}{*}{\multicolumn{2}{|c|}{ Model }} & \multicolumn{2}{|c|}{ Unstandardized Coefficients } & \multirow{2}{*}{$\begin{array}{c}\text { Standardized } \\
\text { Coefficients } \\
\text { Beta } \\
\end{array}$} & \multirow[b]{2}{*}{$\mathrm{t}$} & \multirow[b]{2}{*}{ Sig. } \\
\hline & & B & Std. Error & & & \\
\hline \multirow[t]{3}{*}{1} & (Constant) & 4.052 & 2.761 & & 1.467 & .151 \\
\hline & TOTAL_LK & -.052 & .048 & -.177 & -1.095 & .281 \\
\hline & TOTAL_FIN & .020 & .024 & .135 & .838 & .408 \\
\hline
\end{tabular}

a. Dependent Variable: RES2

Based on Table 1.5, the significance value of the two independent variables is more than 0.05 , namely the financial literacy variable with a value of 0.281 and fintech with a value of 0.408 . Thus, there is no heteroscedasticity problem in the regression model.

\section{Multiple Linear Regression Analysis}

Multiple linear regression is a statistical technique used to analyze the relationship between the dependent variable (dependent) and the independent variable (predictor) (Pramesti, 2014: 113). The purpose of multiple linear regression analysis is to determine the significance of the influence of the predictor variable (independent) on the dependent 
variable, so that it can contain the correct predictions. The results of multiple linear regression analysis can be seen in the following table:

Table 1.6 The result of multiple liner regression analysis

\begin{tabular}{|l|r|}
\hline \multirow{2}{*}{} & Coefficients \\
\cline { 2 - 2 } & B \\
\hline Contanct & 4,514 \\
\hline LK & 0,117 \\
\hline FIN & 0,258 \\
\hline
\end{tabular}

Based on Table 1.6, the multiple linear regression equation in this study is:

$$
\mathrm{KI}=4,514+0,117 \mathrm{LK}+0,258 \mathrm{FIN}+\mathrm{e}
$$

Based on the multiple linear regression equation above, the results are as follows

1. The constant value obtained is 4.514, meaning that if the value of financial literacy (LK) and fintech (FIN) is 0 then the investment decision has a value of 4.514

2. The regression coefficient of the financial literacy variable (LK) is 0.117 means that if other independent variables are of fixed value and financial literacy (LK) has increased by 1 unit, the investment decision (KI) will increase by 0.117 or $11.7 \%$

3. The regression coefficient for the fintech variable (FIN) is 0.258 , meaning that if other independent variables are fixed and fintech (FIN) increases by 1 unit, the investment decision (KI) will increase by 0.258 or $25.8 \%$.

T-test

The t-test aims to determine the effect of the independent variable partially on the dependent variable (Priyatno, 2008: 50). Testing is done by comparing $t$ count with $t$ table or by looking at the significance column in each $t$ count. The results of the t-test can be seen in the following table :

Table 1.7 The result of T-test 


\begin{tabular}{|c|c|c|c|c|c|c|}
\hline \multicolumn{7}{|c|}{ Coefficients $^{a}$} \\
\hline & & \multicolumn{2}{|c|}{ Unstandardized Coefficients } & \multirow{2}{*}{$\begin{array}{c}\text { Standardized } \\
\text { Coefficients } \\
\text { Beta }\end{array}$} & \multirow[b]{2}{*}{$\mathrm{t}$} & \multirow[b]{2}{*}{ Sig. } \\
\hline \multicolumn{2}{|c|}{ Model } & B & Std. Error & & & \\
\hline \multirow[t]{3}{*}{1} & (Constant) & 4.514 & 4.468 & & 1.010 & .319 \\
\hline & TOTAL_LK & .117 & .077 & .165 & 1.514 & .139 \\
\hline & TOTAL_FIN & .258 & .039 & .718 & 6.607 & .000 \\
\hline
\end{tabular}

a. Dependent Variable: TOTAL_KI

\section{First Hypothesis Testing (H1)}

Based on Table 1.7, it is known that the Sig value for the effect of LK on y is 0.139> 0.05 and the $\mathrm{t}$ value is $1.514<\mathrm{t}$ table 2.02619 so it can be concluded that $\mathrm{H} 1$ is rejected, which means there is no influence of LK on Y.

\section{Second Hypothesis Testing (H2)}

It is known that the Sig value for the effect of FIN on Y is equal to $0.000<0.05$ and the $\mathrm{t}$ value of $6.607>\mathrm{t}$ table is 2.02619 , so it can be concluded that $\mathrm{H} 2$ is accepted, which means that there is an influence of FIN on Y.

Hypothesis Testing H3 with the F-test

Table 1.8 The result of F-test

\begin{tabular}{|c|c|c|c|c|c|c|}
\hline \multicolumn{7}{|c|}{ ANOVA $^{a}$} \\
\hline \multicolumn{2}{|c|}{ Model } & $\begin{array}{l}\text { Sum of } \\
\text { Squares }\end{array}$ & df & Mean Square & $\mathrm{F}$ & Sig. \\
\hline \multirow[t]{3}{*}{1} & Regression & 505.191 & 2 & 252.595 & 24.239 & $.000^{b}$ \\
\hline & Residual & 385.584 & 37 & 10.421 & & \\
\hline & Total & 890.775 & 39 & & & \\
\hline
\end{tabular}

a. Dependent Variable: TOTAL_KI

b. Predictors: (Constant), TOTAL_FIN, TOTAL_LK

\section{Third Hypothesis Testing (H3)}

Based on the output above, it is known that the significance value for the effect of LK and FIN simultaneously on $\mathrm{Y}$ is equal to $0.000<0.05$ and the $\mathrm{F}$ value of $24.239>\mathrm{F}$ table 3.24 so that it can be concluded that H3 is accepted, which means that the effect of LK and FIN simultaneously on Y. 


\section{Coefficient of Determination}

The determination test or R square is used to determine how much influence the independent variable has on the dependent variable. According to Priyatno (2008: 79), the analysis of determination in multiple linear regression is used to determine the magnitude of the contribution of the simultaneous influence of the effect of the independent variables $(\mathrm{X} 1, \mathrm{X} 2 \ldots)$ on the dependent variable. The results of the coefficient of determination (R2) can be seen in the following table:

Table 1.9 The result of coefficient determination

\begin{tabular}{l|l|r|r|r|r}
\multicolumn{7}{c}{ Model Summary } \\
Model & $\mathrm{R}$ & R Square & $\begin{array}{c}\text { Adjusted R } \\
\text { Square }\end{array}$ & $\begin{array}{l}\text { Std. Error of } \\
\text { the Estimate }\end{array}$ & $\begin{array}{c}\text { Durbin- } \\
\text { Watson }\end{array}$ \\
\hline 1 & $.753^{\text {a }}$ & .567 & .544 & 3.228 & 2.243 \\
\hline
\end{tabular}

a. Predictors: (Constant), TOTAL_FIN, TOTAL_LK

b. Dependent Variable: TOTAL_KI

Based on the output above, it is known that the R Square value is 0.567 , this means that the simultaneous influence of the financial literacy (LK) and FIN (fintech) variables on investment decisions is $56 \%$, while the remaining $44 \%$ is influenced by other variables not included in this model.

\section{CONCLUSIONS AND SUGGESTIONS}

a. Financial literacy in investment decisions

In this study, financial literacy does not affect investment decisions. This means that the hypothesis is rejected. The $t$ test results show that the $t$ value of financial literacy is 1.154 smaller than $\mathrm{t}$ table (2.02619). In multiple regression analysis, financial literacy has a negative value on investment decisions. This shows that financial literacy alone is not necessarily sufficient for someone to make investment decisions. This is in line with research conducted by (Arianti, 2018; Budiarto \& Susanti, 2017; Pradhana, 2018) which provides research results that financial literacy has no influence on investment decisions. 
It can be seen that people who have high literacy will be more careful in making decisions, and tend not to be easy to make investment decisions because they have many considerations in the future.

b. Fintech in investment decisions

In this study, fintech greatly influences the investment decisions, meaning that the hypothesis is accepted. The $\mathrm{t}$-test results show that the $\mathrm{t}$ value of fintech is greater than $\mathrm{t}$ table (6.607> 2.02619). In the multiple regression analysis, fintech has a positive value on investment decisions. It can be seen that fintech supports someone to make investment decisions easier. This can be seen from the easier access to information and current applications related to the investment sector. It is the evident from 40 respondents, $58 \%$ already have investments using fintech products.

Based on the research results and the conclusions of this study, there is an implication that expected to provide benefit: financial service companies or institutions need to further develop and facilitate current information technology. This is an effort to convey matters related to financial literacy in fintech products to the public so that people will be much easier and faster to respond to investment activities in this country.

\section{REFERENCES}

Alquraan, T., Alqisie, A., \& Al Shorafa, A. (2016). Do Behavioral Finance Factors Influence Stock Investment Decisions of Individual Investors? (Evidences from Saudi Stock Market). American International Journal of Contemporary Research, 6(3), 159-169. Retrieved from www.aijcrnet.com

Arianti, B. F. (2018). The influence of financial knowledge, control and income on individual financial behavior. Economics and Accounting Journal, 1, 1-10.

Aren, S., \& Zengin, A. N. (2016). Influence of Financial Literacy and Risk Perception on Choice of Investment. Procedia - Social and Behavioral Sciences. https:/ / doi.org/10.1016/j.sbspro.2016.11.0 47

Atkinson, A., \& Messy, F.-A. (2012). Measuring Financial Literacy: Results of the Oecd Infe Pilot Study. Oecd, 15, 1-73. https://doi.org/https://doi.org/10.1787/bb2cd70 cen 
Awais, M., Laber, F., Rasheed, N., \& Khursheed, A. (2016). Impact of Financial Literacy and Investment Experience on Risk Tolerance and Investment Decisions: Empirical Evidence from Pakistan. International Journal of Economics and Financial Issues, 6(1), 73-79. Retrieved from http:www.econjournals.com

Billion, A. (2016). FinTech for micro, small and medium sized enterprises. ING Economic Department, (October).

Budiarto, A., \& Susanti, S. (2017). Pengaruh Financial Literacy, Overconfidence, Regret Aversion Bias, dan Risk Tolerance terhadap Keputusan Investasi (Studi pada investor PT. Sucorinvest Central Gani Galeri Investasi BEI Universitas Negeri Surabaya). Jurnal Ilmu Manajemen Universitas Negeri Surabaya, 5(2), 1-9.

Cárdaba, M. A., Briñol, P., Horcajo, J., \& Petty, R. E. (2014). Changing prejudiced attitudes by thinking about persuasive messages: Implications for resistance. Journal of Applied Social Psychology, 44(5), 343-353.

CNBC Indonesia, 2018, "Ini Dia Empat Jenis Fintech di Indonesia", https:// www.cnbcindonesia.com/fintech/20180110145800-37-1126/ini-diaempat-

jenis-fintech-di-indonesia/,Diakses 13-10-2018

Fachrudin, K. R., \& Fachrudin, K. A. (2016). The Influence of Education and Experience Toward Investment Decision With Moderated By Financial Literacy. Polish Journal of Management Studies, 14(2), 51-60. https:/ / doi.org/10.17512/pjms.2016.14.2.0 5

Finansialku.com, 2018, “DefinisiFintech", https://www.finansialku.com/definisifintech-adalah/. diakses 13-10-2018

FSB, 2017, "Financial Stability Implications from Fintech" http://www.fsb.org/wpcontent/uploads/R270617.pdf/. Diakses 12-10-2018

Ghozali. 2011. Aplikasi Analisis Multivariate Dengan Program IBM SPSS 19. Semarang: Badan Penerbit Universitas Diponegoro.

Gozali, Ahmad. 2015. Habiskan Saja Gajimu! Jakarta: TransMedia.

Hansson, S. O. (2005). Decision Theory: A Brief Introduction. Royal Institute of Technology. https:/ / doi.org/http:/ / www.infra.kth.se/ so h/decisiontheory.pdf

Kemendikbud. 2017. Gerakan Literasi Nasional. [Online]. http://gln.kemdikbud. go.id/glnsite/wp-content/uploads/2017/10/literasi-FINANSIAL.pdf (diakses pada 15 Maret 2019).

Koinwork.com, 2018, “Semua yang Perlu Anda Ketahui Tentang Peer to Peer Lending (P2P

Lending"'https:/ / koinworks.com/blog/ketahui-tentang-peer-peer- 
lending/.

Diakses 13-10-2018

Lintner, G. 1998. Behavioral Finance: Why Investors Make Bad Decisions.The Planner, 13 (1), 7- 8. Vol. 68, No.4.

Lusardi, A., \& Mitchell, O. (2007). Financial Literacy and Retirement Preparedness: Evidence and Implications for Financial Education. Business Economics, (January), 35-44. Retrieved from http:/ / link.springer.com/article/10.2145/20070104

Lusardi, A., Mitchell, O. S., \& Curto, V. (2010).

Lusardi, A., \& Mitchell, O. S. (2014). The economic importance of financial literacy: Theory and evidence. Journal of Economic Literature, 52(1), 5-44. https:// doi.org/10.1257/jel.52.1.5

Manurung. Adler H dan Rizky. Lutfi T, 2009. “Succesful Financial Planner: A Complete Guide",Jakarta: Grasindo

Otoritas Jasa Keuangan, 2018,“Penyelenggara Fintech yang Terdaftar di OJK per Agustus 2018".https:// www.ojk.go.id/id/berita-dankegiatan/publikasi/Pages/Penyelenggara-Fintech-Terdaftar-di-OJK-perAgustus-2018.aspx/. Diakses 12-10-2018

Pradhana, R. W. (2018). Pengaruh Financial Literacy, Cognitive Bias, dan Emotional Bias terhadap Keputusan Investasi (Studi pada Investor Galeri Investasi Universitas Negeri Surabaya). Jurnal Ilmu Manajemen Univeritas Negeri Surabaya, 6(3), 108-117.

Pradikasari, E., \& Isbanah, Y. (2018). Pengaruh Financial Literacy, Illusion of Controll, Overconfidence, Risk Tolerance,dan Risk Perception terhadap Keputusan Investasi Pada Mahasiswa di Kota Surabaya. Jurnal Ilmu Manajemen Universitas Negeri Surabaya, 4(2), 424-434.

Pramesti, G. 2014. Kupas Tuntas Data Penelitian dengan SPSS 22. Jakarta: PT Elex Media Komputindo.

Priyatno, D. 2016. SPSS Handbook: Analisis Data, Olah Data dan Penyelesaian Kasus-Kasus Statistik. Yogyakarta: MediaKom.

Priyatno. 2008. SPSS untuk Analisis Korelasi, Regresi, dan Multivariate. Yogyakarta: Gava Media.

Sekaran, U., \& Bougie, R. (2016). Research methods for business: A skill building approach. John Wiley \& Sons. 
Siamsyah. Dhoni, 2016, "Mendorong Crowdfunding untuk Peningkatan Investasi di Indonesia" http:/ / www.kemenkeu.go.id/. Diakses 06-07-2019

Siregar, S. 2014. Metode Penelitian Kuantitatif. Jakarta: Kencana. Siregar, S. 2015. Statistik Parametrik untuk Penelitian Kuantitatif. Jakarta: Bumi Aksara.

Suharso, Puguh. 2009. Metode Penelitian Kuantitatif untuk Bisnis: Pendekatan Filosofi dan Praktis. Jakarta: PT Indeks.

Tendelilin, E. 2010. Portofolio dan Investasi Teori dan Aplikasi. Yogyakarta: Kanisius.

The Journal of Consumer Affairs. The Journal of Consumer Affairs, Vol. 44(No. 2), 22. http://www.councilforeconed.org/wp/wpcontent/uploads/2011/11/Financial-Literacy- for-Young-Lusardi.pdf

Ullah, S. (2015). An Empirical Study of Illusion of Control and Self-Serving Attribution Bias, Impact on Investor's Decision Making: Moderating Role of Financial Literacy. Research Journal of Finance and Accounting Www.iiste.org ISSN, 6(19), 109118. Retrieved from www.iiste.org

Yulianti, N. \& Silvy, M. 2013. “Sikap Pengelola Keuangan dan Perilaku Perencanaan Investasi Keluarga di Surabaya". Journal of Business and Banking, Vol. 3, No. 1: Hlm. 57-68. 